University of Nebraska - Lincoln

DigitalCommons@University of Nebraska - Lincoln

Faculty Publications from the Harold W. Manter Laboratory of Parasitology

4-1998

\title{
Species of Myxobolus (Myxozoa) from the Bulbus Arteriosus of Centrarchid Fishes in North America, with a Description of Two New Species
}

David K. Cone

Saint Mary's University - Canada

Robin M. Overstreet

Gulf Coast Research Laboratory, robin.overstreet@usm.edu

Follow this and additional works at: https://digitalcommons.unl.edu/parasitologyfacpubs

Part of the Parasitology Commons

Cone, David K. and Overstreet, Robin M., "Species of Myxobolus (Myxozoa) from the Bulbus Arteriosus of Centrarchid Fishes in North America, with a Description of Two New Species" (1998). Faculty Publications from the Harold W. Manter Laboratory of Parasitology. 303.

https://digitalcommons.unl.edu/parasitologyfacpubs/303

This Article is brought to you for free and open access by the Parasitology, Harold W. Manter Laboratory of at DigitalCommons@University of Nebraska - Lincoln. It has been accepted for inclusion in Faculty Publications from the Harold W. Manter Laboratory of Parasitology by an authorized administrator of DigitalCommons@University of Nebraska - Lincoln. 


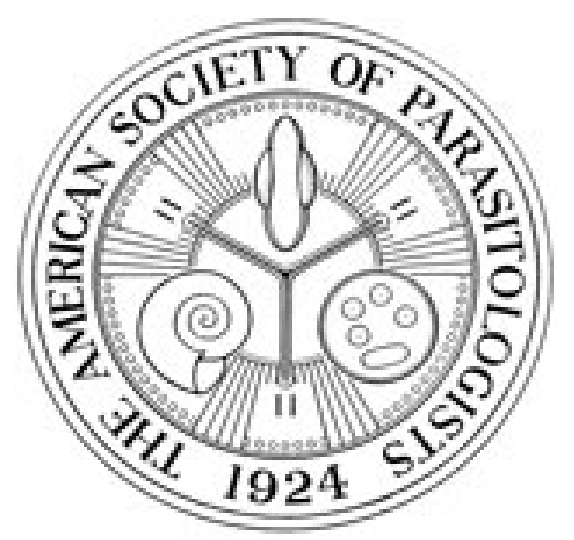

Species of Myxobolus (Myxozoa) from the Bulbus Arteriosus of Centrarchid Fishes in North America, with a Description of Two New Species

Author(s): David K. Cone and Robin M. Overstreet

Source: The Journal of Parasitology, Vol. 84, No. 2 (Apr., 1998), pp. 371-374

Published by: The American Society of Parasitologists

Stable URL: http://www.jstor.org/stable/3284499

Accessed: 02/05/2010 23:34

Your use of the JSTOR archive indicates your acceptance of JSTOR's Terms and Conditions of Use, available at http://www.jstor.org/page/info/about/policies/terms.jsp. JSTOR's Terms and Conditions of Use provides, in part, that unless you have obtained prior permission, you may not download an entire issue of a journal or multiple copies of articles, and you may use content in the JSTOR archive only for your personal, non-commercial use.

Please contact the publisher regarding any further use of this work. Publisher contact information may be obtained at http://www.jstor.org/action/showPublisher?publisherCode=asp.

Each copy of any part of a JSTOR transmission must contain the same copyright notice that appears on the screen or printed page of such transmission.

JSTOR is a not-for-profit service that helps scholars, researchers, and students discover, use, and build upon a wide range of content in a trusted digital archive. We use information technology and tools to increase productivity and facilitate new forms of scholarship. For more information about JSTOR, please contact support@jstor.org.

The American Society of Parasitologists is collaborating with JSTOR to digitize, preserve and extend access to The Journal of Parasitology. 


\title{
SPECIES OF MYXOBOLUS (MYXOZOA) FROM THE BULBUS ARTERIOSUS OF CENTRARCHID FISHES IN NORTH AMERICA, WITH A DESCRIPTION OF TWO NEW SPECIES
}

\author{
David K. Cone and Robin M. Overstreet ${ }^{*}$ \\ Department of Biology, Saint Mary's University, Halifax, Nova Scotia, Canada, B3H 3C3
}

\begin{abstract}
Three species of Myxobolus (Myxozoa, Myxosporea) occur in heart tissue of centrarchids. Myxobolus paralintoni Li and Desser, 1985 from Lepomis gibbosus in Algonquin Park and in Lake Erie, Ontario, has subcircular spores (in plane of spore length) in frontal view (11-13 $\mu \mathrm{m}$ long, 9-10 $\mu \mathrm{m}$ wide, and $5 \mu \mathrm{m}$ thick) with a width-to-length ratio of 1:1.2. Myxobolus jollimorei n. sp. from Lepomis macrochirus in Lake Erie and in the Pascagoula River System, Mississippi, has subcircular spores (in plane of spore width) in frontal view (10.0-11.5 $\mu \mathrm{m}$ long, 12.0-14.5 $\mu \mathrm{m}$ wide, and 6.5-8.0 $\mu \mathrm{m}$ thick) with a width-to-length ratio of 1:0.8. Myxobolus manueli $\mathrm{n}$. sp. from Pomoxis nigromaculatus in Lake Erie has spores $(10-11 \mu \mathrm{m}$ long, 8-10 $\mu \mathrm{m}$ wide, and 6.5-7.0 $\mu \mathrm{m}$ thick) that are nearly circular in frontal view but that have 2 distinct sublateral knobs along the sutural ridge and a width-to-length ratio of 1:1.2. All 3 species occur in the bulbus arteriosus of their hosts where they form small, saucershaped pseudocysts. Free spores were found free in the lumen of the heart and bulbus arteriosus, in bile, and in kidney tissue presses.
\end{abstract}

As a group, histozoic species of Myxobolus Bütschli, 1882 (Myxosporea) infect a diverse set of specific tissues that can include specifically the tegument, eyes, gills, skeleton, glands, kidneys, gonads, scale epithelium, muscle, digestive tract, and nervous system (Shulman, 1966). Although spores have been reported commonly from heart tissue, development of pseudocysts of species of Myxobolus in heart tissue is rare (Bauer et al., 1991; Masoumian et al., 1996).

The present study examines 3 species of Myxobolus from the bulbus arteriosus of centrarchid fishes in North America. Myxobolus paralintoni $\mathrm{Li}$ and Desser, 1985 is reported from $\mathrm{Le}$ pomis gibbosus 2 new species are described, 1 from Lepomis macrochirus and 1 from Pomoxis nigromaculatus.

\section{MATERIALS AND METHODS}

Juvenile and adult pumpkinseed (L. gibbosus) were collected 21 June 1994 from Lake Sasajewan $\left(45^{\circ} 35^{\prime} \mathrm{N} ; 78^{\circ} 30^{\prime} \mathrm{W}\right)$ by setting baited minnow traps. The 13 trapped fish were transported live to the nearby Harkness Fisheries Research Laboratory where they were necropsied the same day. Photomicrographs of fresh spores mounted in $1 \%$ agar were prepared during the necropsies. Infected hearts were fixed in $10 \%$ phosphate-buffered formalin and later embedded in Paraplast for preparation of histological sections. Sections ( $7 \mu \mathrm{m}$ thick) were stained with Harris' hematoxylin and eosin or with Giemsa. Juvenile and adult bluegill (L. macrochirus) were collected 15 September 1994 and 19-26 February 1996 by netting with a seine and angling with hook and line in the Pascagoula River and joining bayous near Vancleave, Mississippi. The September sample of bluegill was fixed immediately in $10 \%$ phosphate-buffered formalin and necropsied later. Heart tissue was sectioned as described above. Photomicrographs were prepared of fixed spores stabilized in $1 \%$ agar mounts. The February sample of bluegill was necropsied fresh. Two specimens of black crappie ( $P$. nigromaculatus) were collected 29 June 1993 by seine netting on a beach near Wheatley, Lake Erie. On 28 March 1995, L. gibbosus (7 specimens), L. macrochirus (7), and Pomoxis macrochirus (5) were collected by trap-netting in Inner Long Point Bay, Lake Erie. These fish were frozen and examined later. All measurements of pseudocysts and spores are presented in micrometers as a mean \pm SD followed in parentheses by the range.

Received 27 January 1997; revised 22 October 1997; accepted 22 October 1997.

* Gulf Coast Research Laboratory, P.O. Box 7000, Ocean Springs, Mississippi 39566.

\section{DESCRIPTION \\ Myxobolus jollimorei n. sp. \\ (Figs. 1-4, 13)}

Description: Pseudocyst gray, spherical to saucer-shaped, 50-300 in diameter. Plasmodium lacking typical ectoplasm near periphery, with spores loosely arranged within interior. Fixed spores $(n=15)$ subcircular (perpendicular to plane of spore length) in frontal view, $11.0 \pm$ 0.5 (10.5-11.5) long, $13.8 \pm 0.7$ (12.0-14.5) wide, $7.5 \pm 0.6(6.5-8.0)$ thick. Spore width-to-length ratio $1: 0.8 \pm 0.5$. Polar capsules broadly pyriform and equal in size, $6.0 \pm 0.3$ (5.5-6.0) long, $3.8 \pm 0.3$ (3.5$4.5)$ wide. Filament coils $6-9$, wound tightly and perpendicular to longitudinal axis of capsule. Intercapsular appendix absent. Sutural ridge folds $6-8$, distributed evenly around spore margin. Iodinophilous vacuole and mucous envelope lacking.

\section{Taxonomic summary}

Type host: Bluegill, L. macrochirus Rafinesque, 1819 (Centrarchidae).

Site of infection: Bulbus arteriosus, within the epipericardium and underlying smooth muscle and elastin. Free spores in kidney tissue.

Type locality: Pascagoula River and associated bayous near Vancleave, Jackson County, Mississippi; other localities: Inner Long Point Bay, Lake Erie, Ontario.

Type specimens: syntypes are spores in Giemsa stained sections in U.S. National Parasite Collection, Beltsville, Maryland, USNPC no. 87588.

Prevalence and intensity of infection: 86\% (6 of 7) of the bluegill (17-18 cm in total length) collected from Inner Long Point Bay and $33 \%$ (2 of 6) of the bluegill (5.2-8.5 cm in total length) collected from the Pascagoula River system 9 September 1995. Intensity of pseudocysts ranged from 1 to 30 pseudocysts.

Etymology: This species is named in honor of Blair Jollimore of Hubbards, Nova Scotia, for a decade of assistance collecting fishes for parasitological studies.

\section{Remarks}

Spores of $M$. jollimorei are relatively large, subcircular spores with prominent polar capsules. They resemble spores of Myxobolus filamentus Grinham and Cone, 1990 (previously recognized as Myxosoma okobojiensis Rice and Jahn, 1943, which, when transferred to Myxobolus, became a homonym of Myxobolus okobojiensis Otto and Jahn, 1943 from Pomoxis sparoides) from gills of smallmouth buffalo (Ictiobus bubalus) and Myxobolus magnaspherus Cone and Anderson, 1977 from the peritoneum of $L$. gibbosus. However, the spores of $M$. filamentus as originally described (see Fig. 3 of Rice and Jahn [1943]) are circular in frontal view as opposed to distinctly subcircular and have polar capsules that are longer relative to spore length (approximately 66\% of spore length in $M$. filamentus versus $55-61 \%$ in $M$. jollimorei). Spores of $M$. 

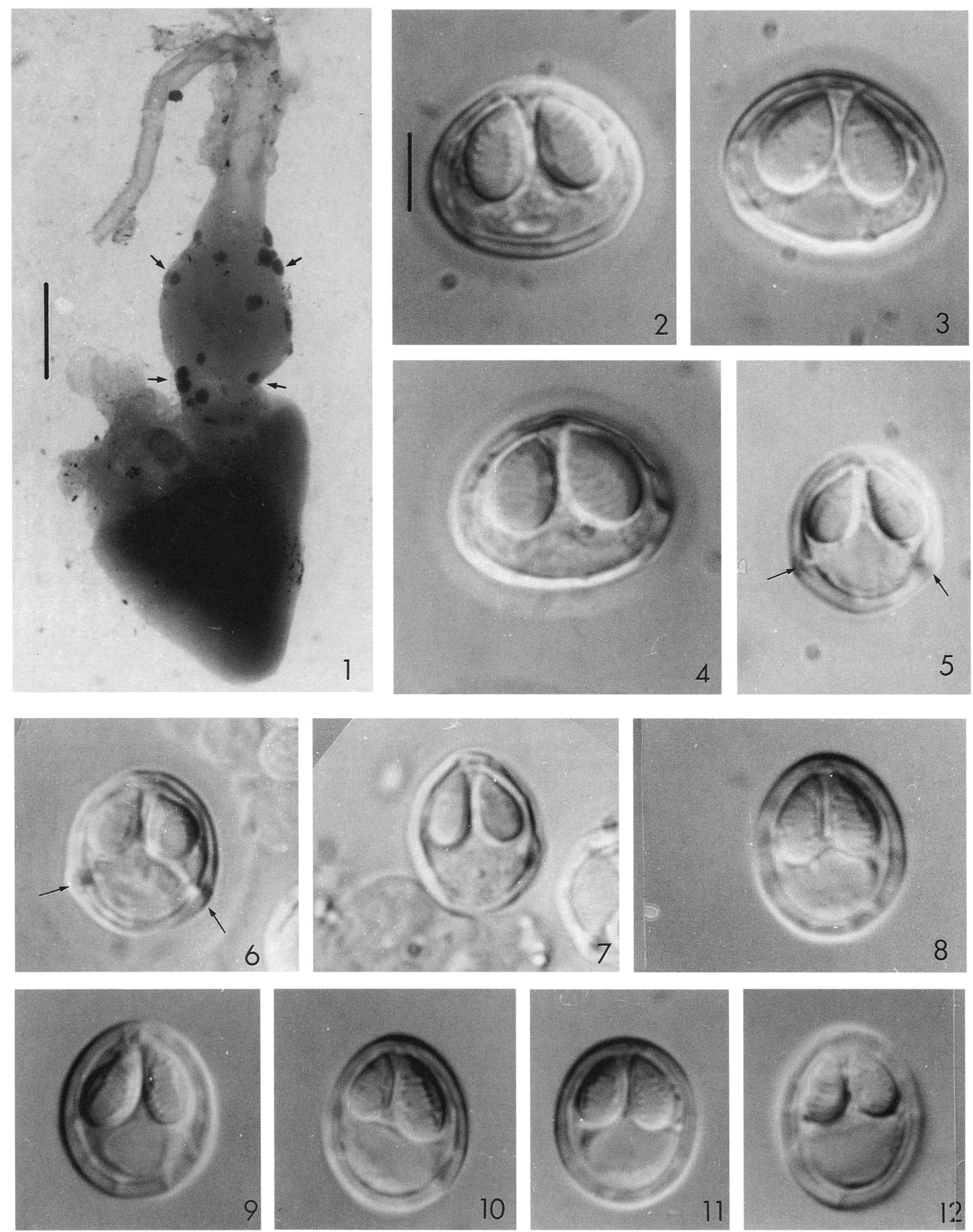

FIGURES 1-12. Myxosporeans from the hearts of centrarchids. 1. Heart of Myxobolus jollimorei $\mathrm{n}$. sp. from Lepomis gibbosus from the Pascagoula River system, Mississippi, with numerous pseudocysts (arrows) within tissues of the bulbus arteriosus. Scale bar $1 \mathrm{~mm}$. 2-4. Developed spores of Myxobolus jollimorei $\mathrm{n}$. sp. in frontal view. 5-7. Developed spores of Myxobolus manueli $\mathrm{n}$. sp. from Pomoxis nigromaculatus in Lake 


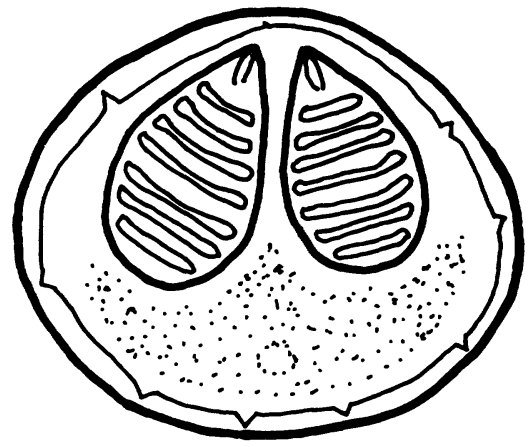

13

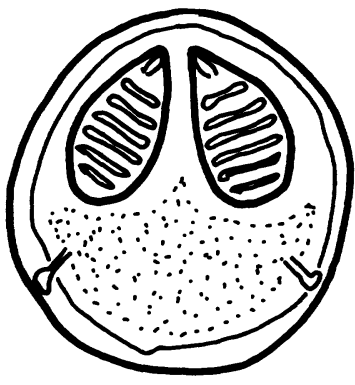

14

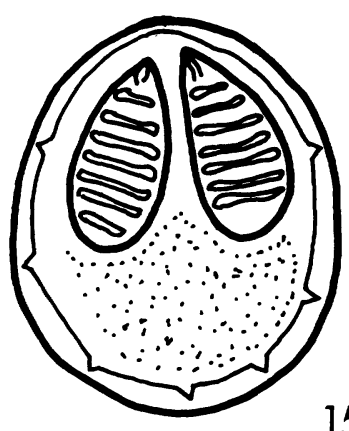

15

FIGURES 13-15. Line drawings depicting typical spores. Scale bar $5 \mu \mathrm{m}$. 13. Myxobolus jollimorei n. sp. 14. Myxobolus manueli $\mathrm{n} . \mathrm{sp}$. 15. Myxobolus paralintoni $\mathrm{Li}$ and Desser, 1985.

magnaspherus have huge polar capsules relative to spore length $(55-$ $61 \%$ in $M$. jollimorei versus 58-68\% for $M$. magnaspherus) (see fig. 3 of Cone and Anderson [1977]; plate 28K of Lom and Dyková [1992]).

\section{Myxobolus manueli n. sp. \\ (Figs. 5-7, 14)}

Description: Pseudocyst gray, spherical to saucer-shaped, 100-800 in diameter. Plasmodium lacking typical ectoplasm from periphery, with spores arranged loosely within interior. Spores subcircular in frontal view, 10.8.0 $\pm 0.5(10-11)$ long, $9.12 \pm 0.9(8-10)$ wide, $7.0 \pm 0.5$ (6.5-7.0) thick. Spore width-to-length ratio 1:1.2 \pm 0.1 . Polar capsules pyriform, $5.3 \pm 0.5(4.5-6.0)$ long and $2.9 \pm 0.8$ (2.5-3.0) thick. Filament coils 6-7, wound tightly and perpendicular to longitudinal axis of capsule. Intercapsular appendix absent. Sutural ridge folds indistinct, with 2 , short sublateral knobs along sutural ridge. Iodinophilous vacuole and mucous envelope lacking.

\section{Taxonomic summary}

Type host: Black crappie, P. nigromaculatus (Lesueur, 1829) (Centrarchidae)

Site of infection: Bulbus arteriosus, within the epipericardium and underlying smooth muscle and elastin. Free spores in kidney tissue and in the lumen of gall bladder.

Type locality: Lake Erie, near Wheatley, Ontario.

Type specimens: Syntypes are spores in Giemsa-stained sections in U.S. National Parasite Collection, Beltsville, Maryland, USNPC no. 87589.

Prevalence and intensity of infection: 57\% (4 of 7) of black crappie (9.5 cm in total length and $21.3-22.3 \mathrm{~cm}$ in total length) collected from Lake Erie; each fish with 1-25 pseudocysts. The two black crappie (25.2 and $29 \mathrm{~cm}$ in total length) examined from the Pascagoula River system were not infected.

Etymology: This species is named in honor of Mr. Frank Manuel of Black Point, Nova Scotia, for his kind assistance to students conducting research under field conditions.

\section{Remarks}

The spore of $M$. manueli $\mathrm{n}$. sp. is unique among known species of Myxobolus from North America in having sublateral knobs along the sutural ridge. A similar sublateral "crest" was reported (Lom and Dyková, 1994) for Myxobolus conei Lom and Dyková, 1994 from the liver and bile ducts of Pseudocaranx dentex caught along the coast of New South Wales, Australia. However, $M$. conei differs significantly from $M$. manueli in having coils (4 and sometimes 5 rather than 6-7) of the polar capsules arranged $45-70^{\circ}$ to the longitudinal axis of the capsule rather than $90^{\circ}$

\section{Myxobolus paralintoni $\mathrm{Li}$ and Desser, 1985 \\ (Figs. 8-12, 15)}

Supplementary data: Pseudocysts gray, spherical to saucer-shaped, $50-600$ in diameter. Plasmodium with poorly defined outer ectoplasm; endoplasm containing loose mass of spores. Fresh spores subcircular in frontal view, $11.8 \pm 0.8(11.0-13.0, \mathrm{n}=8)$ long, $9.6 \pm 0.4(9.0-10.0)$ wide, and 5.0 thick. Spore width to length ratio 1:1.2 \pm 0.1 . Sutural ridge folds $6-8$ in number, distributed evenly around the spore margin. Polar capsules pyriform, $5.2 \pm 0.6$ long and $2.9 \pm 0.3$ wide; filament coils 6-7 in number and perpendicular to the long axis of the capsule. Intercapsular appendix, mucus envelope, and iodinophilous vacuole lacking in fixed specimens.

\section{Taxonomic summary}

Type host: Pumpkinseed, L. gibbosus (Linnaeus, 1758) (Centrarchidae).

Site of infection: Bulbus arteriosus, within the epipericardium and underlying tissue. Phagocytized spores in lumen of bulbous arteriosus.

Type locality: Lake Sasajewan, Algonquin Park, Ontario.

Examined specimens: Syntype slide, Canadian Museum of Nature, Parasite Collection, NMCICP 1984-0364; voucher specimens on hematoxylin and eosin-stained histological sections deposited in U.S. National Parasite Collection, Beltsville, Maryland, USNPC no. 87590.

Prevalence and intensity of infection: 30\% (3 of 9) of L. gibbosus from Lake Sasajewan, and 57\% (4 of 7) of this host from Inner Long Point Bay, Lake Erie, plus 1 of 7 specimens of L. macrochirus from Inner Long Point Bay. Infected fish had 1-38 pseudocysts.

\section{Remarks}

We examined syntypes of $M$. paralintoni. Although the slide with that material had dried and deteriorated, a spore was found and recognized as conspecific to those we collected from the type host (pumpkinseed) on the basis of spore size and shape; these additional specimens also came from the type locality of Lake Sasajewan. Spores in the original description ( $\mathrm{Li}$ and Desser, 1985) were reported as $11 \mu \mathrm{m}$ (9.5-11.5) long, $10.0 \mu \mathrm{m}(9.0-11.5)$, and 6.5-7.5 $\mu \mathrm{m}$ thick, similar to those that we collected. Drawings of spores of $M$. paralintoni provided by Li and Desser (1985), however, resemble those of Myxobolus uvuliferis Cone and Anderson, 1977 from the same host and lake. Rather, as described above, spores of $M$. paralintoni are subcircular in the plane of spore length. Recently, Hayden and Rogers (1997) reported M. par-

Erie. 8-12. Developed spores of Myxobolus paralintoni Li and Desser, 1985 from Lepomis gibbosus in Algonquin Park, Ontario. Scale bar for Figures $2-12$ is $5 \mu \mathrm{m}$. 
alintoni from the bulbus arteriosus of the redbreast sunfish (Lepomis auritus) in the Potomac River, Montgomery County, Maryland. Spores collected by Hayden and Rogers (1997) were identical in size and shape to material examined in the present study.

\section{DISCUSSION}

Myxobolus jollimorei, M. manueli, and M. paralintoni all have a plasmodium that develops specifically within tissues of the bulbus arteriosus of their respective hosts. Plasmodia were not found in any other organ. Histological sections of the heart revealed that spores can disperse from the trophozoite into the lumen of the bulbous arteriosus, where they are presumably put into general blood circulation. The presence of free spores in other organs is the result of such dispersal, and these organs should not be interpreted as alternate sites of plasmodial development. In this regard, the tissue specificity for the three species of Myxobolus appears more restricted than that of $M y x$ obolus bulbocordis Masoumian, Baska and Molnar, 1996, which was reported (Masoumian et al., 1996) from the serosa of the atrium cordis, of the bulbus, and of the larger gill arteries, as well as inside the wall of the bulbus of Barbus sharpeyi in Iran (Masoumian et al., 1996). The restricted tissue development of $M$. paralintoni resembles more closely that of Henneguya sebasta Moser and Love, 1975 and Henneguya spp. that develop in the bulbus arteriosus of rockfish (Sebastes spp.) in the Pacific Ocean (Moser and Love, 1975; Moser et al., 1976) and bluefish (Pomatomus saltatrix) in the Atlantic Ocean (Meyers et al., 1977). Moser and Love (1975) and Moser et al. (1976) reported that the development of $H$. sebasta was restricted to the bulbus, but that free spores tended to aggregate in the lumen of the atrial and ventricular chambers, with isolated spores occurring in the gall and urinary bladders.

Myxosporean infections of the bulbus arteriosus appear to be characterized by significant spore dispersal beyond the plasmodium. This dispersal may be a result of the need for the bulbus arteriosus to expand significantly during the normal cardiac cycle; for rainbow trout (Oncorhynchus mykiss), $25 \%$ of the cardiac stroke volume is taken up by expansion of the bulbous arteriosus (Priede, 1976). This expansion would produce significant compression and stretching of the plasmodium, forces that may facilitate both rupturing of the plasmodium and dispersal of spores through tissues. We note that the plasmodia of the three myxosporeans reported here are saucer-shaped and only loosely filled with spores. Both these features could serve to minimize detrimental effects of compression during early stages of spore development.

The presence of 3 distinct species of Myxobolus in the bulbus arteriosus of 3 sympatric centrarchid fishes raises questions about possible historical relationships. Are these parasites the result of diversification of a species of Myxobolus that parasitized the bulbus arteriosus of an ancestral centrarchid? Or, are the three 3 relatively distant phylogenetically, representing 3 independent invasions of a unique site within centrarchid fishes. The apparent rareness of species of Myxobolus parasitizing this tissue site in other fishes suggests the former hypothesis may be the case. However, the fact that each of the three species is different from each other morphologically and that each resem- bles more closely species of Myxobolus from other hosts in different tissues than among themselves suggest the latter hypothesis may be the case. Molecular studies (e.g., Smothers et al., 1994; Siddall et al., 1995; Schlegel et al., 1996) on these 3 and additional species may help to answer this question.

\section{ACKNOWLEDGMENTS}

This work was supported in part by an NSERC Operating Grant (D. K. C.) and U.S. Department of Commerce, National Marine Fisheries Service Award No. NA76FL0446 and International Paper.

\section{LITERATURE CITED}

BAuER, O. N., V. N. Voronin, AND O. N. YUNCHIS. 1991. Infection of the heart in carp caused by Myxobolus dogieli (Myxosporea, Myxobolidae). Angewandte Parasitologie 32: 42-44.

Cone, D. K., AND R. C. ANderson. 1977. Myxosporidan parasites of pumpkinseed (Lepomisgibbosus L.) from Ontario. Journal of Parasitology 63: 657-666.

HAYDEN, K. J., AND W. A. Rogers. 1997. Redescription of Myxobolus paralintoni (Myxosporea: Myxobolidae), with notes regarding new host and locality. Journal of Parasitology 83: 283-286.

LI, L., AND S. S. DeSSER. 1985. The protozoan parasites of fish from two lakes in Algonquin Park, Ontario. Canadian Journal of Zoology 63: $1846-1858$.

Lom, J., AND I. DyKovÁ. 1992. Protozoan parasites of fishes. Developments in aquaculture and fisheries science, Vol. 2. Elsevier Science Publishers B. V., Amsterdam, The Netherlands, 315 p. , AND - 1994. Studies on protozoan parasites of Australian fishes. III. Species of the genus Myxobolus Bütschli, 1882. European Journal of Protistology 25: 431-439.

Masoumian, M., F. BASKa, AND K. Molnar. 1996. Description of $M y x-$ obolus bulbocordis sp. nov. (Myxosporea: Myxobolidae) from the heart of Barbus sharpeyi (Günther) and histopathological changes produced by the parasite. Journal of Fish Diseases 19: 15-21.

Meyers, T. R., T. K. Sawyer, and S. A. MacLean. 1977. Henneguya sp. (Cnidospora: Myxosporida) parasitic in the heart of the bluefish, Pomatomus saltatrix. Journal of Parasitology 63: 890-896.

Moser, M., AND M. S. Love. 1975. Henneguya sebasta sp. n. (Protozoa, Myxosporida) from California rockfish, Sebastes spp. Journal of Parasitology 61: 481-483.

- $\longrightarrow$, AND L. A. Jensen. 1976. Myxosporida (Protozoa) in California rockfish, Sebastes spp. Journal of Parasitology 62: 690692.

PRIEDE, I. G. 1976. Functional morphology of the bulbous arteriosus of rainbow trout (Salmo gairdneri). Journal of Fish Biology 9: 209-216.

RICE, V. J., AND T. L. JAHN. 1943. Myxosporidian parasites from the gills some fishes of the Okoboji region. Proceedings of the Iowa Academy of Sciences 50: 313-321.

Schlegel, M., J. Lom, A. Stechmann, D. Bernhard, D. Leipe, I. DyKOVÁ, AND M. SOGIN. 1996. Phylogenetic analysis of complete small subunit ribosomal RNA coding region of Myxidium lieberkuehni: Evidence that Myxozoa are Metazoa and related to the Bilateralia. Archiv für Protistenkunde 147: 1-9.

Shulman, S. S. 1966. Myxosporidia of the USSR, Nauka Publishers, Moscow-Leningrad. Translated version published for the United States Department of the Interior and National Science Foundation, Amerind Publishing Co. Pvt. Ltd., New Delhi, India, 1988, 631 p.

Siddall, M. E., D. S. Martin, D. Bridge, S. S. Desser, and D. K. CONE. 1995. The demise of a phylum of protists: Phylogeny of Myxozoa and other parasitic cnidaria. Journal of Parasitology 81: 961-967.

Smothers, J. F., C. D. von Dohlen, L. H. Smith, JR., and R. D. Small. 1994. Molecular evidence that the myxozoan protists are metazoans. Science 265: 1719-1721. 